DOI: http://dx.doi.org/10.33846/hn31206

http://heanoti.com/index.php/hn

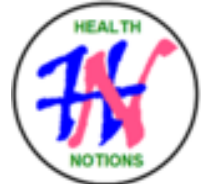

RESEARCH ARTICLE

URL of this article: http://heanoti.com/index.php/hn/article/view/hn31206

\title{
Characteristics of Renal Cell Carcinoma Patients in RSUD Dr Soetomo Surabaya in
} 2014-2017

\author{
Ferdiansyah Rusdhy $^{1(\mathrm{CA})}$, Wahjoe Djatisoesanto ${ }^{2}$, Dyah Erawati $^{3}$, Dyah Fauziah ${ }^{4}$ \\ ${ }^{1(\mathrm{CA})}$ Faculty of Medicine, Universitas Airlangga, Indonesia; fardiasultan7@ gmail.com (Corresponding Author) \\ ${ }^{2}$ Department of Urology, Dr. Soetomo General Hospital, Indonesia; wahjoe.djatisoesanto@fk.unair.ac.id \\ ${ }^{3}$ Department of Radiology, Dr Soetomo General Hospital, Indonesia; dyah-erawati@fk.unair.ac.id \\ ${ }^{4}$ Department of Pathology Anatomy, Dr. Soetomo General Hospital, Indonesia; dyah-f@ fk.unair.ac.id
}

\begin{abstract}
Renal Cell Carcinoma is a type of malignant renal tumour. According to GLOBOCAN 2012 data, it ranked $17^{\text {th }}$ on the most common malignancy in Indonesia with an incidence rate of 1.5 per 100000 citizens. Mortality rates for men is 1.6 per 100000 , while it is 0.8 per 100000 case for women. The clinical symptoms of flank pain, flank mass, and hematuria, are usually only found in patients with later stages of cancer development. This descriptive study aims to present data on characteristics of Renal Cell Carcinoma patients. Data were collected from histopathological medical records of RSUD Dr. Soetomo Surabaya. We found that 25 of 40 patients are male, with most patients aged between 50 to 59 at time of diagnosis. Majority of patients worked as a private sector worker, and had high school level education. They presented with stage 2 tumour, with Clear Cell Renal Cell Carcinoma subtype. All 40 patients were treated by Radical Nephroctomy.
\end{abstract}

Keywords: renal cell carcinoma; characteristics

\section{INTRODUCTION}

\section{Background}

Renal Cell Carcinoma usually present with no clinical symptoms ${ }^{(1)}$. The usual symptoms triad of hematuria, flank mass, and flank pain arises in later stages of tumour development. High death rate might be related to late diagnosis due to limited clinical manifestations during its early stages ${ }^{(2)}$.

Global data reported 337,860 new cases of Renal Cell Carcinoma and 143,406 related deaths in 2012 . A total of 600,000 cases were found in men, and around 300,000 cases in women ${ }^{(3)}$. American Cancer Society reports 63,990 new cases and 16,870 related deaths ${ }^{(4)}$. According to GLOBOCAN 2012 data, it ranked $17^{\text {th }}$ on the most common malignancy in Indonesia with an incidence rate of 1.5 per 100000 citizens. Mortality rates for men is 1,6 per 100000 , while it is 0.8 per 100000 case for women. Epidemiological studies suggest a positive correlation between Human Development Index and Renal Cell Carcinoma morbidity and mortality rates ${ }^{(5)}$.

Late diagnosis is one of the main reason of high death rate related to Renal Cell Carcinoma. In presenting characteristics, diagnosis, and therapy of patients in RSUD Dr. Soetomo Surabaya the writer aims to provide awareness to certain groups, in relation to the diagnosis and therapy of this disease.

\section{Purpose}

To explain the characteristics, diagnosis, and management of Renal Cell Carcinoma patients in RSUD Dr. Soetomo from January 2014 to December 2017.

\section{METHODS}

This study was conducted using retrospective descriptive design, using medical records from 2014 until 2017 in RSUD Dr. Soetomo Surabaya. Total sampling was used as the sampling method of choice. Included in 
this study were patients who had been diagnosed with Renal Cell Carcinoma by histopathology examination in the Department of Pathology Anatomy. Patients diagnosed with other renal malignancy, or unavailable histopathology results were omitted. We collected data from medical records in the Department of Urology. Characteristics presented in this study include age, gender, occupation, education level, tumour staging, histopathological classification, and therapy. Data from a total of 40 patients were put into our data collection sheet, and presented in tables as follows.

\section{RESULTS}

Table 1. Gender and age distribution of renal cell carcinoma patients

\begin{tabular}{ccc}
\hline GENDER & Frequency & Percentage \\
$\bullet$ Male & 25 & 62.5 \\
• Female & 15 & 37.5 \\
\hline AGE & & \\
$\bullet 30-39$ & 3 & 7.5 \\
$\bullet 40-49$ & 12 & 30 \\
$\bullet 50-59$ & 18 & 45 \\
$\bullet 60-69$ & 7 & 17.5 \\
\hline
\end{tabular}

As shown in the table above, we obtained a total of 40 patients diagnosed with Renal Cell Carcinoma. Most of the patients are male, with a total of 25 (62.5\%), while the remaining $15(37.5 \%)$ are female. The youngest patient we found is 30 years old, and the oldest is 66 years old. We found 3 patients $(7.5 \%)$ between the age of $30-39,12$ patients $(30 \%)$ between the age of 40-49, 18 patients $(45 \%)$ between the age of $50-59$, and 7 patients $(17.5 \%)$ between the age of $60-69$.

Table 2. Education level and occupation of renal cell carcinoma patients

\begin{tabular}{lcc}
\hline Education level & Frequency & Percentage \\
- Primary School & 4 & 10 \\
- Secondary School & 6 & 15 \\
- High School & 20 & 50 \\
- Bachelor and above & 4 & 10 \\
- No data & 6 & 15 \\
\hline Occupation & & \\
- Housewife & 7 & 17.5 \\
- Farmer & 7 & 17.5 \\
- Entrepreneur & 4 & 10 \\
- Civil Worker & 5 & 12.5 \\
- Military Worker & 1 & 2.5 \\
- Private Sector Worker & 11 & 27.5 \\
- Unemployed & 2 & 5 \\
- No data & 3 & 7.5 \\
\hline
\end{tabular}

Out of the 40 patients, we found $4(10 \%)$ have a Primary School level education, 6 (15\%) have Secondary School level education, 20 (50\%) have High School level education, and 4 (10\%) have Bachelor level education. Most of them work as a worker on the private sector with a total amount of 11 patients $(27.5 \%)$. The rest work as housewife, farmer, entrepreneur, civil worker, military worker, and unemployed.

Table 3. Histological classification of renal cell carcinoma patients

\begin{tabular}{ccc}
\hline Histological classification & Frequency & Percentage \\
\hline Clear cell RCC & 30 & 75 \\
Papillary RCC & 6 & 15 \\
Chromophobe RCC & 4 & 10 \\
\hline
\end{tabular}

Clear Cell Renal Cell Carcinoma was the most common RCC subtype found in the patients, with more than 30 patients $(75 \%)$. 6 of them (15\%) developed Papillary Renal Cell Carcinoma, while the remaining 4 (10\%) developed Chromophobe Renal Cell Carcinoma. 
Table 4. Tumour staging of renal cell carcinoma patients

\begin{tabular}{ccc}
\hline TNM staging & Frequency & Percentage \\
\hline Stage I & 1 & 2.5 \\
Stage II & 14 & 35 \\
Stage III & 13 & 32.5 \\
Stage IV & 3 & 7.5 \\
No data & 9 & 22.5 \\
Total & 40 & 100 \\
\hline
\end{tabular}

At time of diagnosis, we only found 1 patient $(2.5 \%)$ that presents with Stage I tumour. Most already developed Stage II tumour at time of diagnosis, with the total amount of 14 patients (35\%). Stage III tumour was found in 13 patients (32.5\%), and Stage IV tumour was found in 3 patients $(7.5 \%)$.

Table 5. Therapy of renal cell carcinoma patients

\begin{tabular}{ccc}
\hline Therapy & Frequency & Percentage \\
\hline Radical Nephroctomy & 40 & 100 \\
\hline
\end{tabular}

Radical Nephroctomy is the therapy used in all cases of Renal Cell Carcinoma in this study.

\section{DISCUSSION}

In this study, we found that $25(62.5 \%)$ patients were male, while the other $15(37.5 \%)$ are female. A study shows that Renal Cell Carcinoma is a malignancy that occur mostly in male, with a ratio between male and female of almost $2: 1^{(6)}$. This can be attributed to the increased likelihood of exposure to certain risk factors in male, such as hypertension and history of chronic renal diseases ${ }^{(7)}$. Another study attributes this to the ability of estrogen hormones in inhibiting the proliferation of Renal Cell Carcinoma cells ${ }^{(8)}$.

Most patients in this study were between the age of 50 and 59 years at time of diagnosis, with a total number of 18 patients. Although a study using global data shows that most patients belong to the 60-70 year age group at time of diagnosis, a study in Indian population shows that most of the patients were between 50-59 years of age at time of diagnosis ${ }^{(9)(10)}$. The relatively younger age presentation might be attributed to the poor nutritional level of the younger population in developing countries, which might be analogous to the nutrional level of older population in more developed countries ${ }^{(10)}$.

Half the patients had High School level education, with only $4(10 \%)$ patients had university level education. This finding supports a study which stated that people with less than 12 years of education have a relative risk of twice more than those with 12 years or more of education ${ }^{(11)}$. The high number of patients working as a farmer might be attributed to exposure of chlorine and plant fertilizers ${ }^{(12)}$. Exposure to pepticide and herbicides also increase the likelihood of Renal Cell Carcinoma ${ }^{(13)}$.

We found 30 patients (75\%) with Clear Cell Renal Cell Carcinoma subtype, 6 patients (15\%) with Papillary Renal Cell Carcinoma, and 4 patients (10\%) with Chromophobe Renal Cell Carcinoma. This number is similar to previous studies, with a slightly higher percentage of Chromophobe Renal Cell Carcinoma Patients ${ }^{(2)(14)}$.

This study shows that most patients either present with stage 2 or stage 3 tumour. We found 14 patients (35\%) present with stage 2 tumour, and 13 patients $(32.5 \%)$ present with stage 3 tumour. A study showed that in developed countries, most patients present with stage 1 tumour at time of diagnosis ${ }^{(15)}$. Low healthcare accessibility index in Indonesia might be related to these findings ${ }^{(16)}$. Patients only seek healthcare when symptoms arise, which usually means advanced tumour development.

All 40 patients were treated by Radical Nephroctomy. Tumour staging data shown in table IV supports this therapy of choice. Although 1 patient present with stage 1 tumor, Radical Nephroctomy is preferred due to the relative complexity of Partial Nephroctomy and its multiple complications, which may include haemorrhage and urinary fistula ${ }^{(17)}$. Several studies have shown that both Radical Nephroctomy and Partial Nephroctomy have similar outcome and survival rate ${ }^{(18)(19)}$.

\section{CONCLUSION}

Based on the results of the study, it can be concluded that patients are mostly male, diagnosed between the age of 50-59. Patients mostly work as workers at private companies, with High School level education. Most present with stage 2 tumor and Clear Cell variant. All of them were treated using Radical Nephroctomy. From this study, we can increase our effort in preventive intervention of Renal Cell Carcinoma, as we know this 
disease only present clinical findings in later stages of tumour development. Furthermore, future studies with more patients of Renal Cell Carcinoma are needed. Not only improvements from the amount of the sample study but also improvements for diagnosis of Renal Cell Carcinoma

\section{REFERENCES}

1. IAUI. Guideline on Renal Cancer Management (Panduan Penanganan Kanker Ginjal). Bandung; 2012.

2. Wein A, Kavoussi L. Campbell-Walsh urology. Philadelphia: Elsevier; 2016.

3. Ferlay J, Soerjomataram I, Dikshit R, Eser S, Mathers C, Rebelo M et al. Cancer incidenceand mortality worldwide: Sources, methods and major patterns in GLOBOCAN 2012. International Journal of Cancer. 2014;136(5):E359-E386.

4. Systematic Reviews. 2017;. American Cancer Society. Cancer Facts \& Figures 2017. Atlanta: American Cancer Society; 2017.

5. Mohammadian M, Pakzad R, Towhidi F, Makhsosi B, Ahmadi A, Salehiniya H. Incidence and mortality of kidney cancer and its relationship with HDI (Human Development Index) in the world in 2012. Medicine and Pharmacy Reports. 2017;90(3):286-293.

6. Ljungberg B, Campbell S, Cho H, Jacqmin D, Lee J, Weikert S et al. The Epidemiology of Renal Cell Carcinoma. European Urology. 2011;60(4):615-621.

7. Lucca I, Klatte T, Fajkovic H, de Martino M, Shariat S. Gender differences in incidence and outcomes of urothelial and kidney cancer. Nature Reviews Urology. 2015;12(10):585-592.

8. Yu C, Ho J, Huang Y, Cha T, Sun G, Yu D et al. Estrogen Inhibits Renal Cell Carcinoma Cell Progression through Estrogen Receptor- $\beta$ Activation. PLoS ONE. 2013;8(2):e56667.

9. Capitanio U, Bensalah K, Bex A, Boorjian S, Bray F, Coleman J et al. Epidemiology of Renal Cell Carcinoma. European Urology. 2019;75(1):74-84.

10. Agnihotri S, Kumar J, Jain M, Kapoor R, Mandhani A. Renal cell carcinoma in India demonstrates early age of onset \& a late stage of presentation. Indian J Med Res 2014;140:624-

11. Albano J, Ward E, Jemal A, Anderson R, Cokkinides V, Murray T et al. Cancer Mortality in the United States by Education Level and Race. JNCI: Journal of the National Cancer Institute. 2007;99(18):13841394.

12. Karami S, Lan Q, Rothman N, Stewart P, Lee K, Vermeulen R et al. Occupational trichloroethylene exposure and kidney cancer risk: a meta-analysis. Occupational and Environmental Medicine. 2012;69(12):858-867.

13. Hu J. Renal cell carcinoma and occupational exposure to chemicals in Canada. Occupational Medicine. 2002;52(3):157-164.

14. Leibovich B, Lohse C, Crispen P, Boorjian S, Thompson R, Blute M et al. Histological Subtype is an Independent Predictor of Outcome for Patients With Renal Cell Carcinoma. Journal of Urology. 2010;183(4):1309-1316.

15. Karakiewicz P, Jeldres C, Suardi N, Hutterer G, Perrotte P, Capitanio U et al. Age at diagnosis is a determinant factor of renal cell carcinoma- specific survival in patients treated with nephrectomy. Canadian Urological Association Journal. 2008;2(6):610.

16. Mubasyiroh, Rofingatul \& Nurchotimah, Enung \& Laksono, Agung. (2016). Indeks Aksesibilitas Pelayanan Kesehatan di Indonesia.

17. Norton E. Long-term Survival Following Partial vs Radical Nephrectomy Among Older Patients With Early-Stage Kidney Cancer. JAMA. 2012;307(15):1629.

18. Kunath F, Schmidt S, Krabbe L, Miernik A, Dahm P, Cleves A et al. Partial nephrectomy versus radical nephrectomy for clinical localised renal masses. Cochrane Database of Sytematic Reviews. 2017;

19. Shulyak A, Banyra O. Radical or simple nephrectomy in localized renal cell carcinoma: what is a choice?. Central European Journal of Urology. 2011;64:152-155. 